\title{
Insight
}

\section{Integrated and Adaptive Management of Water Resources: Tensions, Legacies, and the Next Best Thing}

\author{
$\underline{\text { Nathan L. Engle }}^{1,2}, \underline{\text { Owen R. Johns }}^{1}, \underline{\text { Maria Carmen Lemos }}^{1}$, and Donald R. Nelson $^{3}$
}

\begin{abstract}
Integrated water resources management (IWRM) and adaptive management (AM) are two institutional and management paradigms designed to address shortcomings within water systems governance; the limits of hierarchical water institutional arrangements in the case of IWRM and the challenge of making water management decisions under uncertainty in the case of AM. Recently, there has been a trend to merge these paradigms to address the growing complexity of stressors shaping water management such as globalization and climate change. However, because many of these joint approaches have received little empirical attention, questions remain about how they might work, or not, in practice. Here, we explore a few of these issues using empirical research carried out in Brazil. We focus on highlighting the potentially negative interactions, tensions, and trade-offs between different institutions/ mechanisms perceived as desirable as research and practice attempt to make water systems management simultaneously integrated and adaptive. Our examples pertain mainly to the use of techno-scientific knowledge in water management and governance in Brazil's IWRM model and how it relates to participation, democracy, deliberation, diversity, and adaptability. We show that a legacy of technical and hierarchical management has shaped the integration of management, and subsequently, the degree to which management might also be adaptive. Although integrated systems may be more legitimate and accountable than top-down command and control ones, the mechanisms of IWRM may be at odds with the flexible, experimental, and self-organizing nature of AM.
\end{abstract}

Key Words: adaptive capacity; adaptive management; institutional inertia; integrated water resources management; resilience; trade-offs; water governance

\section{INTRODUCTION}

Around the world, complex and multiple changes, such as climate variability and change, increased consumption, and pollution, threaten the long-term sustainability of freshwater systems. In the wake of these changes there is growing concern that water managers may be ill-equipped to respond to these current and emerging threats (Milly et al. 2008). However, despite these concerns, throughout history, water systems managers have been surprisingly open to try new management ideas. For the past few decades, these managers have experimented with both significant management paradigm shifts and massive public works to move, rationalize, conserve, and expand the use of freshwater through space and time. As a result of these experiments, we have learned a lot about the limitations and opportunities of different water management approaches to respond to change. For example, we have learned that because of multiple and sometimes contradictory interests and pressures on water resources, decisions about allocation and distribution cannot be sustainable if fragmented by competition across scales and sectors. We have also learned that management that treats different aspects of water, e.g., hydrological, ecological, and socioeconomic, separately, ignores their inherent interdependency, possibly at the expense of longterm sustainability.

In this context of increasing change and multiple stresses, particularly rising water scarcity and decreasing water quality, two of the most influential ideas in water management to emerge in the past few decades have been integrated water resources 
management (IWRM) and adaptive management (AM). IWRM, whose formal foundations can be traced to the 1977 United Nations Water Conference (Biswas 2004), is geared toward decentralizing institutions around major river basins, or a particular watershed scale, and joining together various elements of water resources planning, such as groundwater and surface water, water quantity and quality, and socioeconomic, hydrological, and ecological aspects of water management. In doing so, it strives to integrate management across multiple scales while incorporating a multitude of stakeholder interests (Blomquist et al. 2005). AM has its roots in resilience theory (Holling 1978), and is primarily concerned with the management of uncertainty through formalized experimentation and processed-based learning (Lee 1993, Huitema et al. 2009).

For the past few decades, scholarly research has informed both approaches, especially research in the areas of common pool resources management, participatory decentralization, and resilience theory. Drawing from a rich context of theory and practice, together these management approaches combine different institutions and mechanisms that aim to broadly: (1) increase effectiveness through integration across social, ecological, and hydrological systems; (2) add legitimacy and promote public acceptance through stakeholder participation, cooperation, decentralization, and democratic decision making; (3) incorporate technical expertise through inclusion of different forms of knowledge and promotion of social learning; and (4) promote flexibility and adaptability through experimentation and learning in managing water resources.

In practice, IWRM or AM rarely accomplish all four of these goals. In a thorough review article comparing IWRM and AM in the water sector, Medema et al. (2008) argue that because these theoretical frameworks are difficult to translate into practice, they mostly fail to provide successful examples of implementation. Table 1 provides the working definitions of IWRM and AM that we use throughout this article. Although the literature is packed with competing definitions and interpretations of these approaches (Medema et al. 2008), we settle on broad definitions from the IWRM and AM communities that capture the major elements of each.

Whereas originally IWRM and AM addressed different issues arising from increasing complexity and uncertainty, there is a growing trend to combine integrated and adaptive approaches into a single framework to accomplish all four of the above outlined goals. Scholars and practitioners have expanded on and recombined many of the basic institutions of IWRM and AM into new forms of management, and although in principle this diversity of options is mostly positive, it can also be confusing. Examples of these blended frameworks can be found in research focusing on adaptive governance and comanagement, which emphasize stakeholder participation and sectoral integration through systematic processes of experimentation, learning, collaboration, and monitoring that attempt to reduce uncertainty (Olsson et al. 2004, Folke et al. 2005, Plummer and Armitage 2007, Nelson et al. 2008, Huitema et al. 2009). They are also common in the resilience literature, which stresses the interdependence of social-ecological systems (SES) and the need to study and govern them in an integrated fashion (Anderies et al. 2004, Cash et al. 2006, Cumming et al. 2006, Folke 2006, Lebel et al. 2006, Walker et al. 2006, Janssen et al. 2007, Plummer and Armitage 2007, Ostrom 2009). Perhaps the most salient empirical example of the combination of these frameworks is the NeWater project (www.newater.info/), which underscores the need for adaptive integrated water resources management (AWM) to address the uncertainty associated with increasingly complex and interconnected problems (Pahl-Wostl et al. 2007).

Although scholars have criticized IWRM and AM separately from one another (McLain and Lee 1996, Blomquist and Schlager 2005, Medema et al. 2008), and as broad-stroke panaceas to water management and governance are increasingly shown to fall short of expectations (Meinzen-Dick 2007), the recent phenomenon of melding IWRM and AM frameworks has received less evaluation thus far in research and practice. Theoretically, these hybrid models often make the assumption that desirable institutions/mechanisms such as decentralization of power, stakeholder participation, social learning, integration, etc., either complement or positively interact with each other. However, because many of these joint approaches have received little empirical attention, questions remain about how such institutions/mechanisms work in practice. This is especially true when considering that the degree to which water management institutions have transitioned toward decentralization and participatory governance may have profound implications on the efficacy and capacity to subsequently embrace 
Table 1. Working definitions of integrated water resources management (IWRM) and adaptive management (AM).

\author{
Working Definitions
}

IWRM "A process which promotes the coordinated development and management of water, land, and related resources,
in order to maximize the resultant economic and social welfare in an equitable manner without compromising
the sustainability of vital ecosystems." Global Water Partnership, www.gwp.org/en/The-Challenge/What-is-
IWRM/

It is based on the Dublin Principles, stating that: "1) freshwater is a finite and vulnerable resource, essential to sustain life, development and the environment; 2) water development and management should be based on a participatory approach involving users, planners and policy makers at all levels; 3) women play a central part in the provision, management and safeguarding of water; 4) water is a public good and has a social and economic value in all its competing uses; and 5) integrated water resources management is based on the equitable and efficient management and sustainable use of water." Global Water Partnership, http://www.gwp.org/en/TheChallenge/What-is-IWRM/Dublin-Rio-Principles/

AM "Seeks to aggressively use management intervention as a tool to strategically probe the functioning of [a system]. Interventions are designed to test key hypotheses about the functioning of the [system]...[it] identifies uncertainties, and then establishes methodologies to test hypotheses concerning those uncertainties. It uses management as a tool not only to change the system, but as a tool to learn about the system...The achievement of these objectives requires an open management process which seeks to include past, present, and future stakeholders. Adaptive management needs to at least maintain political openness, but usually it needs to create it. Consequently, adaptive management must be a social as well as scientific process..."

Resilience Alliance, http://www.resalliance.org/600.php

adaptive processes. In this brief analysis, we explore a few of these questions, using empirical research carried out in Brazil. In particular, we highlight potentially negative interactions, tensions, and trade-offs between different institutions/mechanisms perceived as desirable as research and practice attempt to make systems simultaneously integrated and adaptive. We mainly focus on the use of technoscientific knowledge in water management and governance in Brazil's IWRM model and how it relates to participation, democracy, deliberation, diversity, and adaptability.

\section{FROM DECENTRALIZED AND INTEGRATED TO INTEGRATED AND ADAPTIVE MANAGEMENT}

In the water sector, there has been a global paradigm shift over the past several decades away from traditional command and control to more decentralized and integrated forms of management. More recently, there has been a similar push to adopt more adaptive water management approaches. Each approach seeks to remedy a unique problem: the shortcomings of hierarchical management institutions in the case of decentralization and IWRM, and the challenge of making water management decisions under uncertainty in the case of AM. Only relatively recently has AM become a major player in water resources management. This trend is likely in part because of the increasing rate of complexity in the issues and stressors we face in water management, such as globalization and climate change, and the need to manage these resources in a manner that considers the dynamic nature of SESs. In other words, the shift toward an approach that is at once adaptive and integrated reflects the need for a better way to solve the overlapping structural and procedural problems for which IWRM and AM originally intended to consider, albeit separately. The implementation of decentralized and democratic water governance is assumed to enable a shift toward and the institutionalization of integration, which decision makers have perceived as a more appropriate model for achieving sustainable water management. The proliferation of IWRM experiments around the world has contributed to the institutional arrangements in water resource management that we see today in 
numerous examples throughout developed and developing nations (Blomquist et al. 2005).

However, the implementation of IWRM has been neither seamless nor consistently successful in achieving either decentralization or integration (Lemos and Oliveira 2004, Abers et al.2009, Wester et al. 2003). Most relevant to our arguments in this article, IWRM might have also created conditions that constrain the implementation of AM. As highlighted in the policy and governance literatures, institutions and management tend to be intractable and path dependent once they are in place (North 1990). Such institutional inertia is oftentimes essential for shaping norms and behavior, but the formation of 'rigidity traps' can limit actors within systems affected by these institutions from reorganizing and changing course when more appropriate institutional and management alternatives are proposed (Gunderson and Holling 2002).

In the case of water systems, we argue that there are critical elements of the decentralization and IWRM 'legacy' that need further consideration if the goal is to combine adaptive management institutions with integrated management regimes. For example, although decentralization initiatives have informed IWRM, the extent to which IWRM regimes are actually decentralized has important implications for the types of trade-offs and tensions that decision makers might encounter in practice. As will be discussed in the case of Brazil, IWRM regimes that maintain certain elements of centralized command and control may be more adaptive and flexible at the expense of democratization and participation. To date, research has devoted relatively little attention to these conditions in the adaptive governance and comanagement of water resources literature. Figure 1 presents a simplified summary of how IWRM and AM merge into an adaptive and integrated framework in theory, where the differences among management approaches vary according to their adaptability and their level of institutional and stakeholder integration. While there are likely overlaps between the management approaches depicted in the figure, we list the predominant characteristics most attributable to each approach. We also include command and control in the lower left quadrant to illustrate the transitions that both IWRM and AM represent from this historically dominant management framework. The upper right quadrant represents adaptive and integrated management in which governance of water resources embodies both integrated and adaptive qualities. However, the convergence of these different management styles may lead to trade-offs and tensions evident in practice. The right side of Figure 1 illustrates some of the possible tensions between adaptive and integrated approaches according to different domains, including socio-political, value-based, temporal, and spatial or boundary. We illustrate some of these tensions in practice in the discussion of Brazil's water management.

Practitioners also tend to overlook the imprint that IWRM has left on water resources management in the rush to deploy the adaptive paradigm. For example, recent professional publications and gatherings have called for broad implementation of AM principles, with less consideration given to the challenges and tensions that this may entail, e.g., the American Water Resources Association's special conference on Adaptive Management of Water Resources in 2009. Furthermore, managers are often quick to showcase old practices, e.g., command and control, IWRM, etc., as new ideas, e.g., AM. In many ways, the water management community treats the IWRM framework as a fad of the past, with AM as a new and exciting approach, the next best thing. However, the implementation of IWRM, and before that command and control institutions, established mechanisms, structures, and processes that may constrain the transition of water management into a new framework that is both integrated and adaptive.

We turn to Brazil's water management to illustrate the potential trade-offs and tensions in transitioning to an integrated and adaptive framework. The diversity of social, political, and economic contexts in Brazil permits a detailed exploration of the ways in which tensions between IWRM and AM become evident through practice. In presenting the Brazilian case, we hope to move beyond academic theorization of a combined adaptive and integrated approach, and begin to explicitly consider how managers might overlay the AM framework onto or combine it with the IWRM framework for more effective and sustainable water management.

\section{LEGACIES AND TENSIONS IN BRAZILIAN WATER MANAGEMENT}

IWRM is fundamentally about governance arrangements. However, although IWRM stresses the interconnectedness of catchments and users, 
Fig. 1. A simplified summary of major integrated water resources management (IWRM) and adaptive management (AM) principles, and some potential tensions from merging the two approaches.

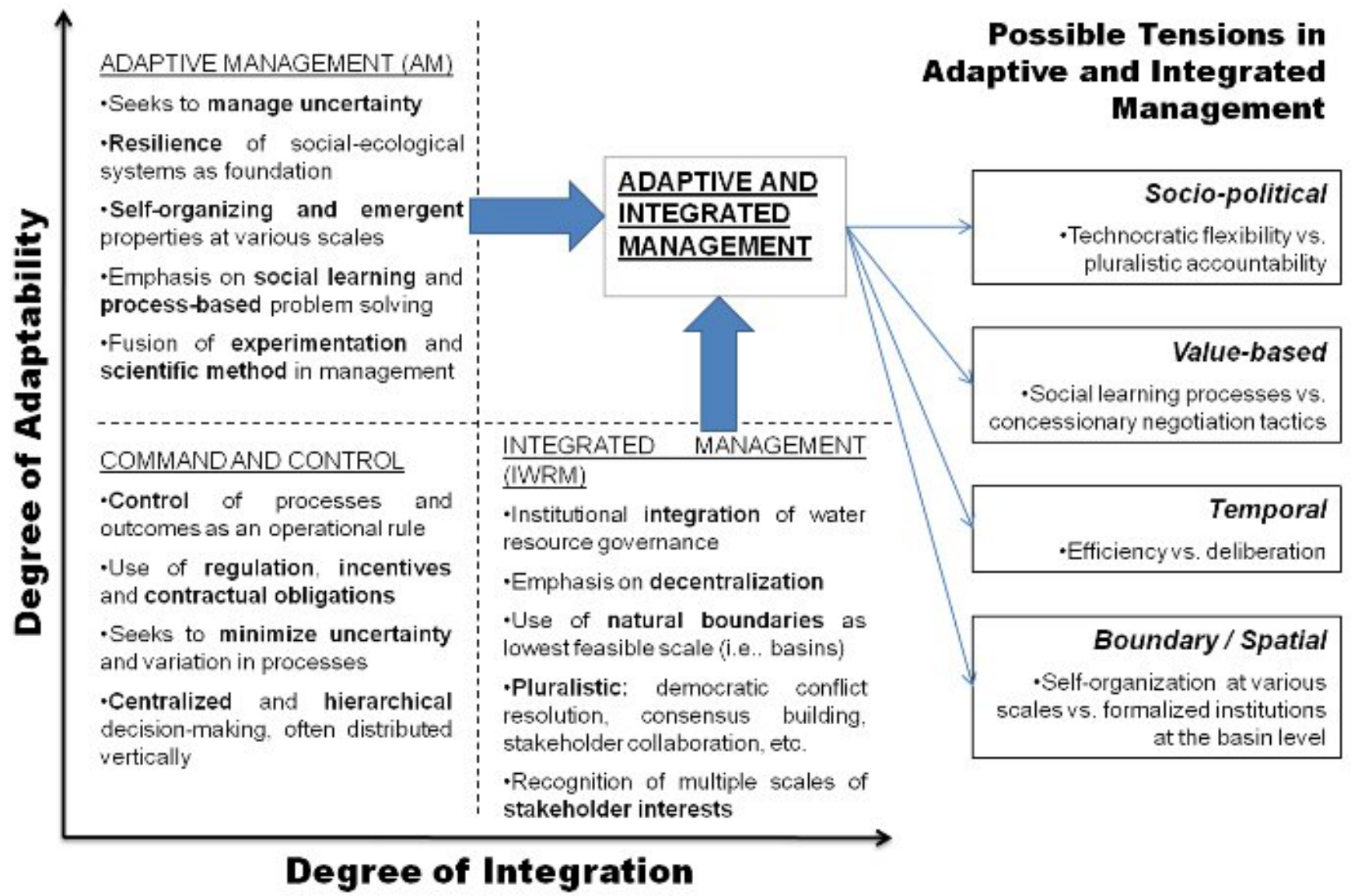

there is no universal model for the way in which management institutions are structured and linked. The diversity of implementation models and the maturity of the IWRM system itself have resulted in differential abilities to incorporate AM principles. These differences are evident in Brazil, where a federal initiative has sought to move water resources management toward IWRM, but where state governments have the leeway to interpret and tailor implementation processes.

Historically, water resources governance in Brazil was centralized under the control of the federal and state governments, which subordinated the goals of water management to the interests of politically powerful sectors such as agriculture and hydropower (Abers 2007). By the early 1990s, policy makers and legislators in states such as São
Paulo and Ceará began to promote the importance of water resource sustainability relative to economic development. Increasingly inspired by integrated management models being implemented in other countries, these actors stressed the integrated nature of water resources and the importance of stakeholder participation in management decisions (Formiga-Johnsson et al. 2007). In response to growing civil pressure and the success of these innovative state-level management initiatives, the Brazilian federal government adopted a new water resources management system in 1997. The principles of the new management model included integrating sectoral policies, devolving watershed management to local river basin councils, and ensuring the active participation of the range of stakeholders in each management area. Although federal legislation provided the broad institutional 
guidelines of the new management model, states have been responsible for fleshing out the details of how the legislation is actually implemented.

Since 1997, all states have formulated water laws that meet the federal requirements and which specify the design and implementation of formal institutions and processes. However, despite the overall emphasis on decentralization, many states have interpreted the ideals of civil society participation, inclusion, and deliberation differently. For example, although all management structures must develop triparty (civil society, users, and state representatives) river basin councils, their composition and level of authority in the management hierarchies differ. São Paulo state requires one-third of all council members to be representatives of civil society organizations. These include research organizations, associations of water users, as well as other organizations specializing in water and socioeconomic issues. Also in São Paulo, municipal representatives have a separate allotment of chairs independent of the civil society sector (Brannstrom et al. 2004), while in Paraná state, only one-fifth of the council must represent civil society, which includes municipal representatives. In the state of Ceará, in addition to the formal river basin council, policy makers organized Users' Commissions, which functioned to support allocation decisions (Lemos and Oliveira 2004). Despite their early success however, such commissions were later disbanded or incorporated into the more formal river basin council. These differences between states and river basins have practical implications for the adaptability of management institutions.

In this context of highly diverse management arrangements, opportunities and constraints for AM differ depending on: (1) the level of decentralization in the basin;(2) patterns of knowledge diffusion and use; and (3) how IWRM institutions and mechanisms, e.g., participation, representation, and integration, shape the overall responsiveness and adaptability or adaptive capacity of decision making, especially in times of stress. For example, the dominance of a small number of technocrats or técnicos, i.e., individuals with a technical background acting as agency support, hired consultants, or members of technical chambers to the councils, over decisions in a more centralized system can facilitate flexibility and experimentation, two important aspects of AM. However, the integration of a broader diversity of stakeholders and different perspectives under more decentralized models enhances legitimacy and brings more locally relevant knowledge to the decision process (mainly important tenets of IWRM), but often at the expense of the flexibility maintained by the smaller, technical team. We turn to recent empirical work in two river basins and two broader studies across a handful of river basins to highlight such potential trade-offs and tensions associated with the various legacies of IWRM implementation and the potential ramifications for adopting a more adaptive style of management.

In the early 1990s, the northeastern state of Ceará implemented IWRM upon the organizing principles of decentralization, integration, and participation of stakeholders. However, as the reform of the state's water sector evolved, it progressively combined attempts to organize democratically structured stakeholder organizations, such as Users' Commissions, with growing centralization of overall management by the state water agency, Cogerh (Company for Water Resources Management, in English; Lemos and Oliveira 2004, FormigaJohnsson and Kemper 2005, Broad et al. 2007). For a while, river basin councils and users' commissions coexisted with a centralized decision making model in which Cogerh was in charge of budget decisions and allocation of resources, and participatory councils had partial input on decisions about water allocation (Lemos and Oliveira 2004, Lemos 2008). For example, in the Jaguaribe-Banabuiú river basin, although Cogerh organized public meetings where the User's Commission could decide on matters of water allocation, the Commission's choices were significantly constrained by three main factors. First, the reservoir scenarios, usually representing six alternatives of water discharge and recharge, provided by Cogerh's técnicos to inform stakeholders' decisions, assumed zero inflow of rainfall from the next rainy season - a very riskaverse position. Second, the agency specified beforehand in the scenarios a set of priorities for water use, including the transfer of drinking water to supply the capital city of Fortaleza, which is located outside the basin. Hence, stakeholders in the User's Commission and River Basin Council had input only into how to allocate the remaining water. However, if Cogerh considered the participatory bodies choice too risky, it could have their decisions overturned by a higher level state water management commission that superseded the basinlevel commissions and councils (Broad et al. 2007, Lemos 2008). Finally, even if the participatory 
bodies' decisions were respected, many stakeholders claimed that because of the way they were constituted, in terms of representation and dominance of certain groups over others, these councils fell short of representing the diversity of interests at the basin level (Ballestero 2004, Taddei 2005, Broad et al. 2007). This includes the interests of less powerful users as well as ecosystem protection and the well-being of future generations as prescribed by adaptive approaches.

In contrast, the centralization of decisions in the hands of the technical agency may facilitate the implementation of experiments as well as afford a level of flexibility that may be incompatible with more decentralized systems. For example, state water managers were able to quickly conceive and implement the experimental Águas do Vale program (or Water of the Valley, in English) in the Jaguaribe basin from 2001-2002, which paid waterintensive agriculture producers not to irrigate during this particularly water-scarce period (FormigaJohnsson and Kemper 2005). Despite mixed results in terms of compliance, the program increased the number of options available for water governance in the region. In sum, the Ceará case illustrates a few of the trade-offs between flexibility (AM) and participation and democracy (IWRM). Interestingly, when questioned about this potential contradiction, técnicos ponder on the side of conservatism, believing that through their risk-averseness they are representing, first, long-term environmental sustainability, and second, equity by representing the interests of those stakeholders that are not part of the participatory councils (Engle and Lemos 2010).

Another in-depth case study focusing on the implementation of IWRM illustrates a different kind of tension between integration and participation and AM. The Paraíba do Sul River basin is the most developed and economically significant in Brazil because it crosses the three wealthiest and most populous states in the country, São Paulo, Rio de Janeiro, and Minas Gerais. In this case, the implementation of IWRM has led both to significant institutional development and complexity and, potentially, to long-term environmental unsustainability (for a detailed description of the case see, FormigaJohnsson et al. 2007). On the one hand, the pioneer development of a complex, polycentric management system across scales was fueled by substantial social learning brokered by técnicos who had built a strong social network across the three states through the years (Kumler and Lemos 2008). In 2004, this network, under the auspices of a river basin council, was able to organize a tristate drought task force that was critical in informing decision making and water allocation through a significant water crisis. Although constituted by the council, the task force functioned virtually independently. The success of this arrangement suggests that the creation of participatory mechanisms does not necessarily imply lack of flexibility, especially when they are willing to delegate decision making to other bodies that can act more nimbly in the face of crisis. Yet, on the other hand it also suggests how difficult it may be to make many of the most important and time-sensitive decisions in the context of broad stakeholder participation. The early dominance of the council by industrial interests yielded a bulk water charging system that benefits the region's industry, potentially at the expense of the basin's long-term sustainability (Formiga-Johnsson et al. 2007). In this system, although the bulk water price's calculation formula includes a pollution fee, it does so at a rate that is unlikely to pay for the environmental services lost, especially in the longterm. Here, the existence of a river basin council allowed for more powerful and better organized interests to legitimately negotiate a system clearly to their advantage. The result is a process that is better than the old command and control system, but that may fall short of meeting sustainability and overall integrated governance goals (FormigaJohnsson et al. 2007).

A broader analysis of watershed council members' perceptions across 18 basins presents another example of possible trade-offs and tensions. This study revealed that reported use of techno-scientific knowledge (TSK) correlated negatively with the distribution of power within the councils, that is, councils where members perceived that power was unequally distributed reported higher levels of technical knowledge use (Lemos et al. 2010). Because, in many councils, técnicos often play a prominent role in producing or disseminating much of the TSK that is available, it is not surprising that the majority of members perceive skewed access to knowledge as a critical source of inequality within river basin councils (Abers et al. 2009). This is also consistent with findings from in-depth case study research focusing on river basin councils, which suggests that even in the context of expanding participation and inclusion of the Brazilian water reform, técnicos can hold disproportionate levels of power in councils' decision making processes 
(Lemos 2008, Abers et al. 2009). For example, in their investigation of technical knowledge use across these 18 Brazilian river basins, Lemos et al. (2010:10) report that:

Our observations of council meetings suggest a complex relationship between water users and técnicos. Whereas members sometimes resent técnicos for their tight control of meeting agendas, for the most part, they seek and appreciate expert support. Indeed even if members believe técnicos carry the heavier 'weight' regarding decision-making, they are also appreciated and well regarded as working to improve decision-making. The councils' strong reliance on Technical Chambers and outside experts (as consultants) to support their decision indicates some level of trust in producers of technical knowledge (Formiga-Johnsson et al. 2007).

These findings suggest that, although the way this relationship works in practice may be compatible with collaboration and trust-building, two characteristics of AM, there may be a trade-off between democratic decision making and technical knowledge use in these councils (IWRM).

Finally, another study comparing the relative adaptive capacity, here defined as the ability to prepare and respond to climate variability and change to minimize impacts, cope with consequences, or take advantage of opportunities, across the same 18 river basin councils sheds further light on these trade-offs (Engle and Lemos 2010). The study covered many of the IWRM and AM principles discussed in this article, e.g., representation, participation, TSK, flexibility, networks, equality of decision making, etc., that are theorized to increase adaptive capacity. It showed that higher levels of implementing these institutional mechanisms were associated with higher adaptive capacity. However, the research also unveiled trade-offs in being able to have high levels of all of these institutional mechanisms across the board in any given river basin. For example, one group of basins had high levels across all of the mechanisms except for one, equality of decision making and information use, suggesting that in practice, certain aspects of water governance might be in conflict with one another. Furthermore, because many of these mechanisms are critical to the IWRM and AM paradigms, it suggests that simultaneously implementing IWRM and AM may be much more difficult in practice than in theory.

\section{CONCLUSION}

The Brazilian experience with water management reform illustrates the potential strain between water management theories expounded in the natural resources discourse and real world practice. Our analysis hopes to illuminate that, although adaptive approaches may indeed be the best way to create management systems that are dynamic and responsive to changing social and environmental pressures, in practice, it is often challenging to reconcile such changes with previous and ongoing management transitions. Water management reform in Brazil provides several examples of successful progressions toward more inclusive and pluralistic governance. However, the push to reorganize management systems has also yielded shortcomings and incomplete transitions. This can be seen in basins where the legacy of technical and hierarchical management has shaped the integration of management, and subsequently, the degree to which these systems might also be adaptive. While integrated systems may be more legitimate and accountable than top-down command and control ones, the mechanisms of IWRM may be at odds with the flexible, experimental, and self-organizing nature of AM. In many ways, systems that exhibit stronger remnants of centralization, e.g., technical bodies, sectoral dominance, etc., seem to be more equipped to make rapid and conjectural decisions in response to surprises than those that have successfully transformed into deliberative, participatory, and pluralistic forums.

This is not to say that IWRM and AM are altogether incompatible, or worse, that command and control is somehow a better system to deal with increasing complexity and uncertainty. The Paraíba do Sul case demonstrates how layered and polycentric institutional relationships that promote sectoral integration can be flexible in times of stress, albeit as a result of temporary delegation of decision making to a small technical body. Still, although we have learned much about the conditions that contribute to robust water management regimes over the past decades, we do not yet fully understand what factors enable systems to be both integrated and adaptive. 
In this sense, it is important that scholars and practitioners consider the implications of existing and previous management traditions when calling for more adaptive institutions. More research is needed to investigate the explicit tensions and tradeoffs among existing water management regimes and novel approaches to address emerging complex stressors. A fuller understanding of the legacies of existing approaches will help to guide implementation of more adaptive management institutions and inform practitioners of the factors that can enable or constrain successful transitions. Specifically, more investigation into the practical limitations in applying adaptive management to integrated water management systems could yield greater understanding of the tensions we have discussed in this analysis, and how they may be reconciled. Empirical evaluation and investigation of the ongoing evolution of hybrid management systems is important to learn more about how to create water management institutions that meet the criteria of being at once efficient, flexible, and legitimate.

Responses to this article can be read online at: http://www.ecologyandsociety.org/voll6/iss 1/art19/ responses/

\section{Acknowledgments:}

The authors would like to thank Andrew Bell for his insight on earlier versions of this manuscript, Paul Runci for reviewing the article, and two anonymous reviewers for excellent comments that helped greatly to improve this publication. This article was made available as Open Access with the support of the University of Michigan COPE Fund, http://lib. umich.edu/cope.

\section{LITERATURE CITED}

Abers, R. N. 2007. Organizing for governance: building collaboration in Brazilian river basins. World Development 35:1450-1463.

Abers, R. N., R. M. Formiga-Johnsson, B. Frank, M. E. Keck, and M. C. Lemos. 2009. Inclusão, deliberação e controle: três dimensões de democracia nos comitês e consórcios de bacia hidrográfica no Brasil. Revista Ambiente \& Sociedade XII:115-132.
Anderies, J. M., M. A. Janssen, and E. Ostrom. 2004. A framework to analyze the robustness of socialecological systems from an institutional perspective. Ecology and Society 9(1): 18. [online] URL: http:// www.ecologyandsociety.org/vol9/iss1/art18/.

Ballestero, A. 2004. Institutional adaptation and water reform in Ceará. Thesis. University of Michigan, Ann Arbor, Michigan, USA.

Biswas, A. K. 2004. Integrated water resources management: a reassessment. Water International $29(2): 248-256$.

Blomquist, W., A. Dinar, and K. Kemper. 2005. Comparison of institutional arrangements for river basin management in eight basins. World Bank Policy Research Working Paper 3636, World Bank, Washington, D.C., USA.

Blomquist, W., and E. Schlager. 2005. Political pitfalls of integrated watershed management. Society \& Natural Resources 18(2):101-117.

Brannstrom, C., J. Clarke, and M. Newport. 2004. Civil society participation in the decentralisation of Brazil's water resources: assessing participation in three states. Singapore Journal of Tropical Geography 25:304-321.

Broad, K., A. Pfaff, R. Taddei, A. Sankarasubramanian, U. Lall, and F. D. de Souza. 2007. Climate, stream flow prediction and water management in northeast Brazil: societal trends and forecast value. Climatic Change 84:217-239.

Cash, D. W., W. N. Adger, F. Berkes, P. Garden, L. Lebel, P. Olsson, L. Pritchard, and O. Young. 2006. Scale and cross-scale dynamics: governance and information in a multilevel world. Ecology and Society 11(2): 8. [online] URL: http://www.ecology andsociety.org/vol11/iss2/art8/.

Cumming, G. S., D. H. M. Cumming, and C. L. Redman. 2006. Scale mismatches in socialecological systems: causes, consequences, and solutions. Ecology and Society 11(1): 14. [online] URL: http://www.ecologyandsociety.org/vol11/iss1/ $\underline{\operatorname{art} 14 / .}$.

Engle, N. L., and M. C. Lemos. 2010. Unpacking governance: building adaptive capacity to climate change of river basins in Brazil. Global Environmental Change 20:4-13. 
Folke, C. 2006. Resilience: the emergence of a perspective for social-ecological systems analyses. Global Environmental Change 16:253-267.

Folke, C., T. Hahn, P. Olsson, and J. Norberg. 2005. Adaptive governance of social-ecological systems. Annual Review of Environment and Resources 30:441-473.

Formiga-Johnsson, R. M., and K. E. Kemper. 2005. Jaguaribe river basin, Ceará, Brazil. In $\mathrm{K}$. E. Kemper, W. Blomquist, and A. Dinar, editors. Integrated river basin management through decentralization. Springer, Heidelberg, Germany.

Formiga-Johnsson, R. M., L. M. Kumler, and M. C. Lemos. 2007. The politics of bulk water pricing in Brazil: lessons from the Paraíba do Sul basin. Water Policy 9:87-104.

Gunderson, L. H., and C. S. Holling, editors. 2002. Panarchy: understanding transformations in human and natural systems. Island Press, Washington, D.C., USA.

Holling, C. S. 1978. Adaptive environmental assessment and management. John Wiley, New York, New York, USA.

Huitema, D., E. Mostert, W. Egas, S. Moellenkamp, C. Pahl-Wostl, and R. Yalcin. 2009. Adaptive water governance: assessing the institutional prescriptions of adaptive (co-) management from a governance perspective and defining a research agenda. Ecology and Society 14(1): 26. [online] URL: http://www.e cologyandsociety.org/vol14/iss 1/art26/.

Janssen, M. A., J. M. Anderies, and E. Ostrom. 2007. Robustness of social-ecological systems to spatial and temporal variability. Society \& Natural Resources 20:307-322.

Kumler, L. M., and M. C. Lemos. 2008. Managing waters of the Paraíba do Sul river basin, Brazil: a case study in institutional change and social learning. Ecology and Society 13(2): 22. [online] URL: http://www.ecologyandsociety.org/vol13/iss2/ $\underline{\operatorname{art} 22 / .}$.

Lebel, L., J. M. Anderies, B. Campbell, C. Folke, S. Hatfield-Dodds, T. P. Hughes, and J. Wilson. 2006. Governance and the capacity to manage resilience in regional social-ecological systems. Ecology and Society 11(1): 19. [online] URL: http: //www.ecologyandsociety.org/vol11/iss1/art19/.
Lee, K. N. 1993. Compass and gyroscope: integrating science and politics for the environment. Island Press, Washington, D.C., USA.

Lemos, M. C. 2008. Whose water is it anyway? Water management, knowledge, and equity in NE Brazil. Pages 249-270 in J. Whiteley, R. Perry, and $\mathrm{H}$. Ingram, editors. Water, place and equity. MIT Press, Cambridge, Massachusetts, USA.

Lemos, M. C., A. Bell, N. L. Engle, R. M. FormigaJohnsson, and D. R. Nelson. 2010. Technical knowledge and water resources management: a comparative study of river basin councils, Brazil. Water Resource Research 46.

Lemos, M. C., and J. L. F. Oliveira. 2004. Can water reform survive politics? Institutional change and river basin management in Ceará, Northeast Brazil. World Development 32:2121-2137.

McLain, R. J., and R. G. Lee. 1996. Adaptive management: promises and pitfalls. Environmental Management 20(4):437-448.

Medema, W., B. S. McIntosh, and P. J. Jeffrey. 2008. From premise to practice: a critical assessment of integrated water resources management and adaptive management approaches in the water sector. Ecology and Society 13(2): 29. [online] URL: http://www.ecologyandsociety.org/vol13/ iss2/art29/.

Meinzen-Dick, R. 2007. Beyond panaceas in water institutions. Proceedings of the National Academy of Sciences 104(39):15200-15205.

Milly, P. C. D., J. Betancourt, M. Falkenmark, R. M. Hirsch, Z. W. Kundzewicz, D. P. Lettenmaier, and R. J. Stouffer. 2008. Stationarity is dead: whither water management? Science 319:573-574.

Nelson, R., M. Howden, and M. S. Smith. 2008. Using adaptive governance to rethink the way science supports Australian drought policy. Environmental Science \& Policy 11:588-601.

North, D. C. 1990. Institutions, institutional change, and economic performance. Cambridge University Press, New York, New York, USA.

Olsson, P., C. Folke, and F. Berkes. 2004. Adaptive comanagement for building resilience in socialecological systems. Environmental Management 34:75-90. 
Ostrom, E. 2009. A general framework for analyzing sustainability of social-ecological systems. Science 325:419-422.

Pahl-Wostl, C., P. Kabat, and J. Möltgen, editors. 2007. Adaptive and integrated water management. Coping with complexity and uncertainty. Springer Verlag, Berlin, Germany.

Plummer, R., and D. Armitage. 2007. A resiliencebased framework for evaluating adaptive comanagement: linking ecology, economics and society in a complex world. Ecological Economics 61:62-74.

Taddei, R. 2005. Of clouds and streams, prophets and profits: the political semiotics of climate and water in the Brazilian Northeast. Dissertation. Columbia University, New York, New York, USA.

Walker, B. H., L. H. Gunderson, A. P. Kinzig, C. Folke, S. R. Carpenter, and L. Schultz. 2006. A handful of heuristics and some propositions for understanding resilience in social-ecological systems. Ecology and Society 11(1): 13. [online] URL: http://www.ecologyandsociety.org/vol11/iss1/ art13/.

Wester, P., D. J. Merrey, and M. de Lange. 2003. Boundaries of consent: stakeholder representation in river basin management in Mexico and South Africa. World Development 31:797-812. 